\title{
A Constituição da República de Cuba de 2019: ampliação democrática e regulação econômica como desafios do tempo presente ao socialismo real
}

Recebido: 00-00-2019

Aprovado: 00-00-2019

Enzo Bello ${ }^{1}$

Maria Lúcia Barbosa ${ }^{2}$

\section{Introdução}

$\mathrm{O}$ atual processo de modificação estrutural do Estado materializado no Projeto de Reforma da Constituição de Cuba aprovado pela Assembleia do Poder Popular em 21 e 22 de julho de 2018 é fruto da necessidade de atualização do modelo econômico impulsionado desde a década de 90. A reforma foi submetida a referendo popular, que ocorreu em 24 de fevereiro de 2019. De acordo com as informações divulgadas pela comissão eleitoral, a chamada nova Constituição da República de Cuba foi aprovada por $86,85 \%$ dos votos. Votaram no referendo 7,8 milhões de eleitores, dentre os quais $9 \%$ votaram contra a aprovação do novo texto, 2,53\% votaram em branco e 1,62\% dos votos foram considerados nulos (Doimeadios Guerrero; Carmona Tamayo; Pérez, 2019).

A proposta de alterações em relação à Constituição de 1976 foi fruto do VI Congreso y la Primera Conferencia Nacional del Partido Comunista Cubano, que teve como diretriz o

\footnotetext{
${ }^{1}$ Doutor em Direito pela Universidade do Estado do Rio de Janeiro (UERJ). Estágio de Pós-Doutorado em Direito pela Universidade do Vale do Rio dos Sinos (UNISINOS). Estágio de Pós-Doutorado em Serviço Social pela Universidade Federal do Rio de Janeiro (UFRJ). Professor Associado 1 da Faculdade de Direito da Universidade Federal Fluminense (UFF). Professor e ex-coordenador do Programa de Pós-Graduação em Direito Constitucional (PPGDC) da UFF. Editor-chefe da Revista Culturas Jurídicas (www.culturasjuridicas.uff.br). Membro do Núcleo de Estudos e Projetos Habitacionais e Urbanos (NEPHU) da UFF. Email: enzobello@gmail.com

${ }^{2}$ Doutora em Direito pela Universidade Federal de Pernambuco (UFPE). Professora Adjunta 1 da Faculdade de Direito da Universidade Federal de Pernambuco (UFPE). Líder do Grupo de Pesquisa Asa Branca UFPE. Membro do Grupo de Pesquisa REC-Recife Estudos Constitucionais. Secretária da Comissão de Estudos Constitucionais e Cidadania da OAB/PE. E-mail: malubarbosa1@yahoo.com.br
} 
processo de fortalecimento da institucionalidade e a necessidade de que a Constituição reconheça uma realidade social, econômica e política que de fato já existe na Ilha. Nesse sentido, na primeira sessão ordinária da VIII legislatura da Assembleia Nacional do Poder Popular, em julho de 2013, o então presidente Raúl Modesto Castro Ruz fez um pronunciamento defendendo um modelo econômico e social cubano de desenvolvimento socialista, com base no Plano Nacional de Desenvolvimento Econômico e Social até 2030.

A atual reforma constitucional nasceu com a expectativa de solucionar questões que desde a Constituição de 1976 e as reformas constitucionais de 1978, 1992 e 2002 permaneceram insatisfeitas no sistema socioeconômico, político e jurídico. Todavia, também representam um enorme desafio de se compatibilizar investimentos privados na Ilha e algumas formas de propriedade com a manutenção do socialismo como meta e fim do Estado.

O texto votado em 2019 é composto por preâmbulo, 229 artigos, divididos em 11 títulos, 24 capítulos e 18 seções, disposições transitórias em 13 artigos e disposições finais em 2 dispositivos. Da Constituição de 1976 foram mantidos 11 artigos, modificados 113 e eliminados 13.

O projeto reafirma o caráter socialista do sistema político, econômico e social, bem como o papel dirigente do Partido Comunista de Cuba. O conceito de Estado Socialista de Direito reforça a institucionalidade e a supremacia da Constituição. O sistema econômico mantém os princípios essenciais da propriedade socialista, ao passo que legitima e reconhece a propriedade privada, o papel do mercado e a regulação estatal sobre os investimentos estrangeiros na Ilha.

Quanto ao desenho institucional dos órgãos do Estado, inclui-se as figuras do Presidente da República, com mandato de 5 anos e função de chefia de Estado, e do Primeiro Ministro, com atribuições de Governo, devendo ambas serem preenchidas mediante eleição entre os deputados da Assembleia Nacional do Poder Popular. Nos órgãos de Estado também se apresenta como novidade o Conselho Eleitoral Nacional, instituição de caráter permanente.

Até o presente momento ${ }^{3}$, poucos textos foram divulgados e/ou produzidos no Brasil sobre a Constituição de Cuba de 2019 - tanto de perfil acadêmico (Burgos Matamoros, 2019), como de opinião (Mares, 2019) -, especialmente na área do Direito ou versando sobre temas jurídicos de interesse nas Ciências Sociais. Esse fato não surpreende e se assemelha ao caso da Venezuela. Em nosso entender, tal se deve ao caráter polêmico que se conferiu a esses dois

\footnotetext{
${ }^{3}$ Este artigo foi finalizado e submetido para avaliação em setembro de 2019.
} 
países, sobretudo por (ainda) reivindicarem projetos socialistas de sociedade em pleno século XXI. Ao se tratar de Cuba e Venezuela, na política e na academia oscila-se entre paixão e ódio, informação e desinformação.

Por outros motivos, ainda não foram produzidos muitos textos em Cuba sobre a nova Constituição, já que os/as professores/as cubanos/as dedicam-se atualmente a participar da elaboração de um conjunto de normas que possibilitem a regulamentação infraconstitucional da nova Carta. Ademais, preferem dar o tempo necessário para identificar a eficácia da nova Constituição e como esta se materializará do ponto de vista social e econômico ${ }^{4}$.

Posicionamo-nos a partir do Brasil e adotamos uma postura crítica que rejeita, por um lado, uma posição de neutralidade científica suposta pelo positivismo e, por outro, um olhar alheio à realidade. Numa tentativa de aproximação com o novo constitucionalismo latinoamericano, o objetivo do presente texto é apresentar e discutir a Constituição da República de Cuba de 2019, em especial as vertentes de ampliação de mecanismos democráticos e de implementação de mudanças no sistema econômico ${ }^{5}$, com destaque para o reconhecimento da propriedade privada e o aumento de incentivos aos investimentos estrangeiros no país.

No primeiro tópico é exposto, em linhas gerais, o texto da Constituição proposta e aprovada pela Assembleia do Poder Popular, destacando-se temas e dispositivos voltados à tentativa de democratização do exercício do poder constituinte com vistas a uma aproximação com o constitucionalismo democrático latino-americano.

No segundo tópico é enfatizado o conjunto de questões relativas às propostas de mudanças no perfil e na destinação da economia, em especial o reconhecimento normativo da propriedade privada. Por fim, no terceiro tópico é abordado o conjunto de dispositivos referentes à escolha e ao mandato do Presidente da República e do Chefe de Governo.

A metodologia adotada na elaboração deste texto envolve pesquisa qualitativa, com manejo de raciocínio dedutivo e indutivo, e referencial teórico-metodológico na teoria crítica da sociedade capitalista (Horkheimer, 1983), na teoria crítica do Direito (Lyra Filho, 2000) e na teoria socialista do direito (iusmaterialismo) (Salamanca Serrano, 2011a, 2011b). A pesquisa tem perfil multidisciplinar e teórico-normativo, articulando os campos do Direito Constitucional, da Economia e da Política. As técnicas de pesquisa utilizadas consistem em

\footnotetext{
${ }^{4}$ Informação obtida no contato com professores/as cubanos/as que direcionam seus trabalhos na regulação infralegal do texto constitucional e preferem não aguardar o tempo necessário para aferir a efetividade do texto.

5 Tal escolha se deve à delimitação de objeto para a presente pesquisa, sobretudo considerando que já foram abordados detalhadamente por Mylai Burgos Matamoros (2019) outros temas relevantes, tais como os direitos humanos e suas garantias.
} 
revisão bibliográfica e análise documental. As fontes de pesquisa são documentos legislativos, artigos e livros acadêmicos, além de dados extraídos de órgãos oficiais, jornais e periódicos, sobretudo, cubanos.

As principais noções ou categorias teóricas (e respectivos/as autores/as) trabalhadas no texto são as seguintes: democracia agonística (Laclau, 2013; Mouffe, 1996, 2015); democracia contra o Estado (Marx, 2005; Lenin, 2017; Abensour, 1998); democracia e/ou Constituição (Marx, 2002); democracia contra o capitalismo (Wood, 2003); neoliberalismo (Dardot, Laval, 2016, 2017); economia da dependência (Santos, 2015); novo constitucionalismo latino-americano (Ávila Santamaría, 2016; Bello, 2018, Barbosa, 2015); constitucionalismo crítico (Pisarello, 2011; Sanín Restrepo, 2011); processos constituintes (Pisarello, 2014).

\section{A Tentativa de Democratização do Exercício do Poder Constituinte. Uma aproximação com o constitucionalismo democrático latino-americano?}

Constitucionalismo, Poder Constituinte, Processo Constituinte, Constituição. Até outrora monopolizadas por juristas e cientistas políticos, essas noções têm sido cada vez mais de conhecimento público e discussão em diversas áreas do conhecimento. Para além de questões técnicas e acadêmicas, existe um denominador comum subjacente a todas elas: a democracia. Polissêmica por natureza, a democracia apresenta diferentes concepções de acordo com contextos históricos e pontos de vista teóricos e/ou ideológicos, ao contrário da naturalização de determinada acepção (liberal) que invoca a pretensão de ser a única existente ou aceitável de democracia.

A democracia é um significante vazio, por isso comporta tantos significados (Laclau, 2013). Buscar sentido original na democracia seria de pouca serventia, tanto para aumentar o conhecimento sobre as experiências democráticas, sobre o fenômeno em si, como para elevar as possibilidades concretas de sua ampliação. O antagonismo político constrói significados diversos para esse significante a partir do conflito social e da disputa de poder. E esse é um assunto inacabado (Arblaster, 1988), pois antes de defendê-la é preciso criá-la e recriá-la constantemente.

Isto posto, consideramos fundamental para este texto evidenciarmos e estabelecermos 
como premissa a concepção de democracia que adotamos e sua relação com a Constituição ${ }^{6}$, para que possa haver coerência nas análises e na compreensão, bem como no manejo de conceitos, categorias e autores/as. Inseridos no campo da teoria crítica, tomamos como base a compreensão de Marx (2005) de democracia material como autogoverno do povo ${ }^{7}$, e adotamos como desdobramentos mais contemporâneos a visão da democracia agonística (Laclau; Mouffe, 2015) e da democracia econômica (Wood, 2003). Essas posições não se compatibilizam com o capitalismo e o mercado, que ressignificaram a democracia numa vertente minimalista, a da democracia liberal (eleitoral) (Bobbio, 1997), limitada a garantir procedimentos eleitorais e direitos no plano formal, mas que na prática é conjugada com desigualdades socioeconômicas, pobreza, exploração do trabalho, e concentração da riqueza e dos meios de produção em poucos particulares.

Sobre as relações entre Constituição e democracia, adotamos a seguinte compreensão:

Na prática, como demonstrou Karl Marx [no livro 18 de Brumário] ao analisar a dinâmica política e constitucional da França em meados do século XIX, a Constituição é peça estratégica na engrenagem histórica do processo de luta de classes, adotada por regimes democráticos e autoritários. Via de regra reflete os interesses da classe social hegemônica e é usada para a conservação da ordem social estabelecida; excepcionalmente pode incorporar conquistas parciais da classe social contra hegemônica e ser manejada para transformações materiais, sem ruptura com o modo de produção capitalista (Bello, 2019, p. 9).

Dessa maneira, a Constituição reconhece interesses da classe social hegemônica com vistas a possibilitar uma cristalização de seus interesses econômicos e políticos. Eventualmente contempla interesses sociais como expressões de conquistas parciais da classe

\footnotetext{
${ }^{6}$ Isso é vital para a análise de quaisquer temas, sobretudo quando se trata de conjunturas que envolvem polêmicas, como é o caso de Cuba; a depender do que se entenda por democracia, pode-se sustentar que esse ou aquele país é democrático ou não, dependendo dos critérios e dos referenciais. São comuns na área do direito opiniões pela não existência de democracia em Cuba e na Venezuela, calcadas em autores europeus e liberais, cujas lentes são incompatíveis com a realidade histórica e política dos países latino-americanos. Nesse sentido: "Os textos de brasileiros na área do Direito sobre a Venezuela abordam o conceito de democracia unicamente a partir de argumentos teóricos-institucionais liberais (a poliarquia de Robert Dahl, a democracia liberal de Norberto Bobbio e a democracia de livre mercado de Friedrich August Von Hayek, Milton Friedman, Francis Fukuyama e até Margaret Thatcher), que não condizem com os referenciais ideológicos e teóricos de países e governos de outros contextos, como o do chavismo, e vice-versa. Ou seja, analisa-se um objeto mediante lentes previamente incompatíveis com ele, o que, por óbvio, leva a conclusões de inadequação entre ambos". (Bello, 2019, p. 3).

${ }^{7}$ A posição de Marx acerca da democracia é radical, na medida em que entende que a democracia só pode ser concebida na chave "demos + kratos", em que o poder é do povo, motivo pelo qual considera ter sido a democracia aprisionada ao Estado moderno pela burguesia e sua forma representativa (posteriormente, eleitoral), consoante ao capitalismo e garantidora da sua manutenção. Assim, a verdadeira democracia estaria no espaço das relações sociais, independentemente da forma histórica do Estado burguês, caracterizando-se como democracia contra o Estado (Marx, 2005; Lenin, 2017; Abensour, 1998) e, mais recentemente, democracia contra o capitalismo (Wood, 2003).
} 
trabalhadora, limitados pelos ditames fundamentais das liberdades e direitos civis. Esse é o chamado constitucional clássico ou constitucional liberal, do qual o pensamento crítico tenta resgatar a democracia (Sanín Restrepo, 2011).

As sociedades contemporâneas são sociedades hiper-complexas que não devem ser limitadas apenas à variável de classe, já que os marcadores de gênero, raça, orientação sexual, dentre outros, são determinantes nas disputas políticas na atualidade em sociedades marcadas pela colonialidade (Quijano, 2000). Dada a multiplicidade de interesses e expectativas, tem-se uma incessante disputa de narrativas e de poder. Assim, na prática, as relações sociais são essencialmente conflitivas e os intentos de eliminar o poder e o antagonismo das relações humanas, como parecem supor os modelos deliberativos, estarão fadados ao fracasso.

Faz-se necessário que se busque meios que transformem os inimigos em adversários, o que na acepção de Chantal Mouffe e Ernesto Laclau (2015) produz importantes consequências. Um inimigo, como já referido, é alguém a quem deve-se destruir, com o qual se estabelece uma relação antagônica no sentido mais estrito do termo. Um adversário, por outro lado, é alguém com cujas ideias não se concorda, mas preserva-se o direito de defendêlas. O antagonismo corresponde a uma luta entre inimigos, já agonismo é uma disputa entre adversários. No antagonismo o objetivo é destruir o outro, no agonismo o adversário é alguém com quem se busca, na dialética política, disputar poder (Mouffe, 2015, 1996).

No "pluralismo agonístico" o objetivo da política democrática não é a eliminação do outro, mas pressupõe-se a existência conflitiva da dimensão humana, buscando transformar os inimigos em adversários dentro de regras estabelecidas pelo jogo democrático (Mouffe, 2015).

A sociedade cubana atual é complexa (Burgos Matamoros, 2018), no sentido da existência de vários grupos de interesses, por vezes antagônicos, que perseguem a construção de uma democracia agonística. A Constituição de 2019 é formulada na expectativa de contemplar uma complexidade de interesses econômicos, de grupos identitários, da população LGBTQI+, dos defensores de direitos humanos e daqueles/as que defendem interesses políticos de criação de regras do jogo para o exercício da função de representação política. Por tal maneira, as modificações constantes no texto de 2019 decorrem da expectativa de construção de uma democracia agonística impulsionada pelas transformações ocorridas no constitucionalismo latino-americano das últimas décadas. 
Com base nessas premissas, passamos a examinar o processo constituinte, a Constituição de Cuba de 2019 e suas possíveis relações com o novo constitucionalismo latino-americano.

A Constituição cubana de 2019 se apresenta como um impulso de aproximação com o novo constitucionalismo latino-americano, ao possibilitar que o projeto de Constituição passasse pelo crivo da cidadania, por meio de consulta e posterior ratificação do texto final, com vistas a garantir a oitiva de todos os atores sociais interessados.

O referendo de aprovação do texto constitucional, precedido de um prazo para debate pela sociedade civil, demonstra preocupação com a busca de aproximação do recente processo constituinte com os processos constitucionais ocorridos na América Latina nas últimas décadas, ao dispor sobre a consulta popular na elaboração do texto e na posterior ratificação.

El proceso de consulta que se propone desarrollar es expresión del carácter democrático y participativo del Estado revolucionario y constituye un ejercicio del poder soberano del pueblo, devenido este en órgano constituyente de la nación, lo que nos distingue favorablemente de otros procesos desarrollados en diversos países. ${ }^{8}$ (Cuba, 2019).

Os processos constitucionais ocorridos na América Latina a partir da década de 1990 tiveram por característica um protagonismo cidadão na elaboração dos projetos de Constituição e na posterior ratificação dos textos constitucionais (Barbosa, 2015), especialmente nos casos de Venezuela (Bello, 2019), Bolívia (Valença, 2018) e Equador (Ávila Santamaría, 2016). Dessa maneira, a participação cidadã representou um elemento deflagrador do processo constituinte e também correspondeu a um elemento formal de legitimidade dos novos textos constitucionais. Estes caracterizam um resgate da teoria clássica dos Processos Constituintes teorizada pelo abade Emmanuel-Joseph Sieyès (Bonavides, 2018, p. 148), no sentido de que os cidadãos, detentores do poder soberano, se reconhecem e concordam diretamente com o texto constitucional que foi criado ${ }^{9}$.

Do ponto de vista formal, a Constituição cubana promoveu um diálogo das instituições com a cidadania ao proporcionar a participação da sociedade por meio de plebiscito e

\footnotetext{
${ }^{8}$ Tradução livre do original: O processo de consulta que se propõe desenvolver é expressão do caráter democrático e participativo do Estado revolucionário e constitui um exercício do poder soberano do povo, tornado órgão constituinte da nação, o que nos distingue favoravelmente de outros processos desenvolvidos em diversos países.

${ }^{9}$ Ao invés da idealização de Sieyès e sua naturalização da política, no campo crítico Gerardo Pisarello (2014) considera os processos constituintes na chave das condições materiais e suas contradições, nas quais há disputas pela e na elaboração dos textos constitucionais por parte das forças políticas representantes das diferentes classes sociais.
} 
referendo. Também foi incluída a possibilidade de proposição de emenda constitucional e de leis pela cidadania, o que parece ser um avanço em face da Constituição anterior.

O Partido Comunista Cubano (PCC) é descrito no artigo $5^{\circ}$ do texto como o único existente e como força dirigente superior da sociedade e do Estado. Como o texto de 1976, o atual posiciona o PCC acima das instituições do Estado, conferindo-lhe a centralidade nos debates e nas orientações políticas. Trata-se de desenho institucional diferenciado em relação à construção liberal e que suscita posicionamentos contrários que o consideram de "ideologia totalitária" por suposta falta de pluralismo e diversidade de opiniões (Bonavides, 2000, cap. 24).

A origem dos partidos políticos está calcada numa construção moderna do século XIX, na Europa e nos EUA, baseada em sociedades estratificadas (daí a etimologia da palavra "partido": partir, fracionar, quebrar), dividas em classes, em que os diferentes grupos sociais se institucionalizam numa forma política-jurídica para disputarem eleições e representarem no espaço do Estado os interesses desses respectivos setores. O partido político é um equivalente institucional político-jurídico da segregação de classes sociais. Inicialmente, os partidos políticos eram os partidos da classe dominante, a burguesia. Com os anos, determinados grupos de esquerda seguiram o mesmo caminho, entendendo necessária disputa de poder no espaço da institucionalidade; todavia, a história mostra que perderam sua força e vitalidade no campo estatal em meio aos partidos da ordem estabelecida, majoritários e ricos, e no campo social, com a desmobilização dos quadros políticos de base. Algo comparável ao que, em "A legalização da classe operária", Bernard Edelman (2016) sustenta quanto à greve, que perdeu a sua força questionadora da ordem posta quando foi transformada de prática subversiva e ilícita em direito tutelado pelo Estado.

A justificativa para a adoção do modelo de partido único em Cuba advém da experiência soviética, em que se entendia pela desnecessidade da existência de mais de um partido em uma sociedade sem divisão de classes, na qual o partido político é a personificação da subjetividade coletiva por excelência do socialismo, o proletariado (Lenin, 2017), sem que sejam desconsideradas as suas diferenciações internas. No estágio de transição do socialismo ao comunismo ("sociedade regulada"), o partido político realizaria a mediação entre a sociedade civil e a sociedade política (distinção meramente metodológica, e não orgânica), conformando o Estado Integral ou Ampliado. A partir do papel do partido político como "intelectual coletivo" fundamental no processo de reforma da consciência, a construção da 
sociedade regulada (o autogoverno dos trabalhadores para os trabalhadores) ocorre com a dissolução da sociedade política na sociedade civil (Gramsci, 2007, p. 244-5), a abolição das classes sociais e a formação de um novo bloco histórico, extinguindo-se as formas históricas burguesas do partido político e do próprio Estado.

No caso cubano, já existiam mecanismos de democracia direta na Constituição de 1976, que foram mantidos em 2019, que permitem a participação cidadã ativa e perene, nos espaços estatal e social. Em países que contemplam mecanismos de democracia direta (listados adiante), os cidadãos não precisam estar filiados a partidos políticos para exercerem participação política direta na sociedade civil e/ou junto ao Estado. Em Cuba ocorre o mesmo via PCC - que media as esferas da sociedade civil e da sociedade política, ainda que não haja filiação formal, pois na prática todos os cidadãos cubanos integram o partido organicamente, podendo exercer funções ou cargos, se desejarem, e devendo cumprir deveres cívicos para com a coletividade, independentemente de suas vontades.

Assim, os cidadãos que não integram os quadros formais do PCC ou que divergem diretamente de suas orientações não deixariam de ter suas opiniões difundidas e representadas, havendo pluralidade em termos participativos, necessária ao exercício da democracia, sobretudo nos espaços locais (bairros, províncias etc.), que podem e devem ser disputados para fazerem prevalecer na prática a pluralidade de posições.

Todavia, mesmo considerado essa argumentação, nossa crítica vai no sentido da excessiva burocratização e hierarquização da estrutura, de maneira que a participação no micro (assembleias locais, comitês de defesa da revolução) geralmente não alcança diretamente o macro, o topo da institucionalidade (ANPP e Comitê Central do PCC), o que produz uma estratificação entre parlamento e povo, similar à que Lenin (2017) identificou e criticou no início do século XX na democracia liberal, na qual o parlamento não contém representantes populares e não veicula interesses da classe trabalhadora.

Um fenômeno parecido acontece atualmente na Bolívia e já foi objeto de críticas semelhantes por especialistas com imersão na realidade social e política daquele país (Valença, 2018). A Constituição de 2009 salienta muito elementos como autonomia, pluralismo e sociedade civil, mas na prática dos governos Morales/Linera prevalece um "estadocentrismo" desde a promulgação da Constituição vigente; a sociedade civil não participa tanto quanto se imaginava, mesmo existindo os canais institucionais e de autonomia (Autoridades Indígenas Originárias Campesinas - AIOCs), pois não há uma abertura 
significativa das comportas para as pessoas e grupos sociais participarem. Assim como em Cuba, o problema não nos parece ser da estrutura institucional, mas da prática que tem sido adotada.

Outra questão relevante na Constituição de Cuba de 2019 quanto ao exercício dos poderes de Estado encontra-se no título VI, capítulo II, que trata da Assembleia Nacional do Poder Popular e do Conselho de Estado, cuja descrição versa sobre as competências dos referidos órgãos e revelando uma concentração de poderes na Assembleia Nacional.

A Assembleia Nacional do Poder Popular é o parlamento da República de Cuba e o órgão supremo do poder do Estado. Contém atualmente 605 membros eleitos pelo sistema distrital para um mandato de cinco anos. A Assembleia é o parlamento unicameral e o único órgão detentor do poder constituinte e legislativo na República de Cuba, conforme previsão do artigo 103 da atual Constituição: "La Asamblea Nacional del Poder Popular es el único órgano con potestad constituyente y legislativa en la República".

São muitas as competências da Assembleia Nacional, dentre as quais as de detentora do poder constituinte originário e derivado; interpretar a Constituição; exercer controle de constitucionalidade; revogar acordo ou atos contrários a constituição; revogar decretos presidenciais contrários à Constituição e às leis; discutir e aprovar os objetivos gerais e metas dos planos anuais de desenvolvimento econômico e social a médio e longo prazo; discutir e aprovar o orçamento; estabelecer e instituir tributos, dentre outras. Em nossa opinião, a formatação e os amplos enormes poderes da Assembleia Nacional do Poder Popular denotam um posicionamento acima do Presidente da República, o que pode ser compreendido como uma forma de se descentralizar o poder no contexto pós Fidel e Raúl, em que já não há sujeitos inquestionáveis como os combatentes da revolução.

Ou seja, a Assembleia Nacional do Poder Popular assume funções executivas, legislativas e judiciárias, sendo o único órgão com poder constituinte e legislativo. O povo cubano pode diretamente propor emendas à Constituição, nos termos do artigo 227 por proposta dirigida ao Conselho Eleitoral Nacional por, no mínimo, cinquenta mil eleitores, o que aproxima a atual Constituição cubana das constituições do novo constitucionalismo latino-americano.

Em consonância com o artigo 103, o artigo 227, a Constituição só poderá ser reformada pela Assembleia Nacional do Poder Popular mediante acordo firmado em votação nominal por maioria não inferior a dois terços do número total de integrantes do parlamento, 
caracterizando-se como uma Constituição rígida, sobretudo em razão das cláusulas pétreas previstas no artigo 229.

O projeto de reforma inclui o socialismo e o sistema político como cláusulas pétreas irrevogáveis ${ }^{10}$ no artigo 224 :

En ningún caso resultan reformables los pronunciamientos sobre la irrevocabilidad del sistema socialista establecidos en el artículo 4, y la prohibición de negociar bajo las circunstancias previstas en el inciso a) del artículo $16 .{ }^{11}$ (Cuba, 2018).

É necessária ratificação pela cidadania por meio de referendo popular quando o objeto da reforma constitucional disser respeito a funções da Assembleia Nacional do Poder Popular ou do Conselho de Estado, às atribuições ou ao mandato do Presidente da República, assim como a direitos, deveres e garantias previstos na Constituição, em conformidade com o artigo 228.

A alteração constitucional cubana assegura aos cidadãos a iniciativa popular mediante proposta à Assembleia Nacional. O artigo 227 prevê que as reformas ou emendas constitucionais são de competência da Assembleia Nacional do Poder Popular e enumera como legitimados a proporem reformas à Constituição: o presidente da República, o Conselho de Estado, o Conselho de Ministros, um terço dos deputados da Assembleia Nacional do Poder Popular, o Conselho Nacional da Central dos Trabalhadores de Cuba e as direções das demais organizações de massa e sociais e os cidadãos, mediante petição dirigida à Assembleia Nacional do Poder Popular, subscrita no Conselho Eleitoral nacional, por, no mínimo, cinquenta mil eleitores, deixando pendente de regulamentação legal o procedimento para realização da proposta popular de reforma constitucional, ou seja, norma de eficácia contida, sujeita a regulamentação futura (Silva, 2018).

Também são da alçada da Assembleia Nacional do Poder Popular as funções de eleger o presidente e vice-presidente da República, o primeiro ministro, os integrantes do Conselho de Estado; designar a proposta do presidente ao primeiro ministro e vice-primeiros ministros e demais membros do conselho de ministros; eleger o Presidente do Tribunal Supremo Popular

\footnotetext{
${ }^{10}$ Mylai Burgos Matamoros critica a manutenção de símbolos do socialismo, ainda que em caráter meramente retórico, no preâmbulo da Constituição de 2019, por entender que normas jurídicas não transformam a realidade, e que "os conteúdos substanciais do articulado constitucional caminham em direção a um lugar diferente, um socialismo classista ou um capitalismo de estado, apenas decifrável na medida em que a sociedade cubana avance no futuro" (2019, p. 23-24).

11 Tradução livre: "ARTIGO 224. Em nenhum caso resultam reformáveis os pronunciamentos sobre a irrevogabilidade do socialismo estabelecidos no artigo 4, e a proibição de negociar nas circunstancias do inciso a) do artigo 16 ".
} 
e a chefia do Ministério Público e o Procurador-Geral da República, dentre outras atribuições, o que demonstra a significativa concentração de poderes da Assembleia, nos termos do art. 104 da atual Constituição cubana.

A participação popular foi contemplada no referendo de aprovação do projeto de Constituição e envolve a possibilidade de participação posterior da cidadania no processo de emendas ou reformas, em conformidade com as constituições do novo constitucionalismo latino-americano - venezuelana, equatoriana e boliviana -, as quais possibilitam aos cidadãos a proposição de emendas constitucionais e dispõem que as emendas aos textos serão aprovadas após a ratificação popular por meio de referendo ${ }^{12}$.

A Constituição de Cuba de 2019 inclui como cláusulas pétreas matérias atinentes à segurança nacional e à opção política pelo socialismo. Já eventuais reformas que envolvam temas referentes ao sistema de governo e direitos e garantias dependem de ratificação popular.

Por seu turno, os textos constitucionais formulados no contexto do novo constitucionalismo latino-americano preveem a iniciativa popular ${ }^{13}$ de lei e de reforma da Constituição $^{14}$, revogatória ${ }^{15}$ de mandato de Presidentes da República e outras autoridades públicas, assim com dos demais cargos eletivos, plebiscitos e referendos em matéria constitucional, de modo a alargar a participação popular na vida política dos países.

Em que pese haver previsão da participação popular na Constituição cubana de 2019, o texto não deixa claro como se materializará essa participação, sobretudo no caso do instituto da revogatória de mandato, nem desenha os limites e possibilidades da participação popular no artigo 80.

ARTÍCULO 80. El ciudadano cubano tiene derecho a participar en la conformación, ejercicio y control del poder del Estado, en razón a esto puede, de conformidad con la Constitución y las leyes:
a) estar inscripto en el registro electoral;
b) proponer y nominar candidatos;
c) elegir y ser elegido;
d) participar en elecciones, plebiscitos, referendos, consultas populares y otras formas de participación democrática;

\footnotetext{
12 Artigos 343 e 345, da Constituição da Venezuela de 1999; Artigo 103, da Constituição do Equador de 2008; Artigo 411, da Constituição da Bolívia de 2009.

13 Artigos 74, 173, 204.7, 308, 341.1, da Constituição da Venezuela de 1999; Artigos 61.3, 97, 103, 104, 134.5, 277.6, 318, 329, 331, 420, 442, da Constituição do Equador de 2008; Artigos 11.2.I, 95.III, 162.I.1, 163.2, 240.III, da Constituição da Bolívia de 2009.

14 Artigo 342, da Constituição da Venezuela de 1999; Artigo 442, da Constituição do Equador de 2008; Artigo 411, I e II, da Constituição da Bolívia de 2009.

15 Artigo 6, 70, 71, 72, 197, 233, 339 da Constituição da Venezuela de 1999; Artigos 105, 106, 146.6 da Constituição do Equador de 2008; Artigos 11.2, 157, 170, 171, 195.1, 240, 242.5, 286.2, da Constituição da Bolívia de 2009.
} 
e) pronunciarse sobre la rendición de cuenta que le presentan los elegidos;

f) revocar el mandato de los elegidos

g) ejercer la iniciativa legislativa y de reforma de la Constitución;

h) desempeñar funciones y cargos públicos, y

i) estar informado de la gestión de los órganos y autoridades del Estado. ${ }^{16}$ (CUBA, 2018).

Chama a atenção o protagonismo da Assembleia Nacional do Poder Popular, que assume majoritariamente as funções estatais executivas, legislativas e de controle judiciais de constitucionalidade. O rol exemplificativo do artigo 108 da Constituição cubana de 2019 vai da alínea "a" até a alínea "x", atribuindo ao órgão desde funções de aprovar leis às de revogar decretos presidenciais, criar e extinguir órgãos da administração central e fazer controle de constitucionalidade de leis e atos do poder executivo. Ou seja, desenha-se uma acumulação de atribuições na Assembleia Nacional, que concentra as principais funções do Estado Moderno.

A partir desses elementos, realizamos uma comparação da Constituição de 2019 com as do novo constitucionalismo latino-americano, mediante os seguintes elementos: (i) referências ao socialismo e modelos econômicos; (ii) processos constituintes; (iii) democracia direta e participação política.

Na Constituição da Venezuela de 1999 não há previsão acerca do socialismo; em 2005, o então presidente Hugo Chávez anunciou a plataforma política e econômica do "socialismo do século XXI" como alternativa ao neoliberalismo. Na Constituição do Equador de 2008 também não há previsão sobre o socialismo; os governos de Rafael Correa adotaram o lema da "revolução cidadã" para a refundação do país, como superação ao colonialismo através de um sistema econômico "social e solidário" numa "relação dinâmica e equilibrada entre sociedade, Estado e mercado" (art. 283). Já na Bolívia, a Constituição de 2009 prevê um modelo de "economia plural" que "articula as diferentes formas de organização econômica sobre os princípios de complementariedade, reciprocidade, solidariedade, redistribuição, igualdade, segurança jurídica, sustentabilidade, equilíbrio, justiça e transparência”, complementada por uma "economia social e comunitária", conjugando-se "o interesse individual com o viver bem coletivo" (art. 306.III). O "socialismo comunitário" consiste em modelo econômico subjacente à figura do "Vivir Bien" (Suma Qamaña) (art. 306.I) e em

\footnotetext{
${ }^{16}$ Tradução livre: "ARTIGO 80. O cidadão cubano tem direito a participar na conformação, exercício e controle do poder do Estado, em razão disto pode, de conformidade com a Constituição e as leis: a) estar inscrito no registro eleitoral; b) propor e nominar candidatos; c) eleger e ser eleito; d) participar em eleições, plebiscitos, referendos, consultas populares e outras formas de participação democrática; e) pronunciar-se sobre a prestação de contas que lhe apresentam os eleitos; f) revogar o mandato dos eleitos; g) exercer a iniciativa legislativa e de reforma da Constituição; h) desempenhar funções e cargos públicos; e i) estar informado da gestão dos órgãos e autoridades do Estado."
} 
programa de governo para 2015/2020.

Em termos de processos constituintes, é possível afirmar que as experiências do novo constitucionalismo latino-americano e a recente de Cuba se assemelham em termos de mobilização social e participação política desde abajo. Nas suas diferentes estruturas e dinâmicas houve expressiva participação popular, em termos quantitativos e qualitativos, nas proposições e debates, destacando-se em todas elas a utilização de referendo e os índices elevados de aprovação pelas respectivas populações: Venezuela (71,78\%), Equador (63,93\%), Bolívia (61,43\%) e Cuba (86,85\%) (Barbosa, 2015; Bello, 2018, p. 99-127).

No que tange à democracia direta e às formas de participação política cidadã, qualquer comparação dos mecanismos previstos no novo constitucionalismo latino-americano e na carta cubana de 2019 devem considerar que as vias adotadas são diferentes. Devido ao que já afirmamos acerca da estrutura e do funcionamento do modelo do partido único, consideramos que os canais de participação são similares, embora diferentes, e apresentam deficiências mais em termos de práticas que de estrutura.

Diante do exposto, não consideramos a Constituição cubana de 2019 como inserida no âmbito do novo constitucionalismo latino-americano, nem em termos históricos nem de articulação com os processos de movimentos sociais. Ela tem um desenvolvimento próprio, a partir de uma cultura política e jurídica consolidada que os demais países não tinham, pois seus textos são recentes (1999, 2008 e 2009) e advêm de quebras significativas (não totais) com os regimes anteriores, sobretudo quanto à herança colonizadora (Quijano, 2000). No caso de Cuba isso ocorreu de forma abrupta em 1959 e propiciou o texto constitucional de 1976, que vem sendo atualizado através de constantes reformas constitucionais que visam a adaptar aos novos tempos a disciplina que a redação originária conferiu aos desenhos sociais e institucionais da revolução, o que não é o caso dos demais países. Além disso, são diferentes as visões de participação política e até mesmo de socialismo. Por fim, não há na Constituição de Cuba de 2019 previsão acerca de temas centrais no chamado constitucionalismo andino, tais como: Estado plurinacional, pluralismo jurídico, interculturalidade, jurisdição especial indígena. Todavia, o estabelecimento de relações de proximidade e distanciamento é fundamental para a compreensão da conjuntura constitucional, política e econômica da América Latina no início do século XXI. 


\section{Mudanças de Atualização do Modelo Econômico e a Propriedade Privada}

O assumidamente liberal-igualitário Roberto Gargarella (2010), em "A Sala de Máquinas da Constituição: dois séculos de constitucionalismo latino-americano", divide os duzentos anos de constitucionalismo na América em cinco períodos: (a) o primeiro dizia respeito à fase conservadora, da independência até meados do século XIX (1810 a 1850); (b) o segundo ao republicanismo, que foi até o final do século XIX (1850 a 1890), sendo considerado como o período dos anos fundacionais quando as principais constituições foram formuladas para consolidar a estrutura legal do pós-independência; (c) o terceiro foi o período da crise do modelo pós-colonial marcado pelas ideias positivistas referentes ao liberalismo, do término do século XIX até início do XX; (d) a quarta fase foi a do constitucionalismo social, que se iniciou após a crise de 1930 e culminou com a Segunda Guerra Mundial, a substituição de importações e a entrada da classe trabalhadora na política, conforme a mentalidade do bem-estar social; (e) e, por fim, a quinta fase iniciou-se ao cabo do século XX até o início do seguinte, período do "Novo Constitucionalismo Latino-Americano", quando houve reformas constitucionais mais profundas e significativas.

Embora se alinhe às duas primeiras fases continentais, a experiência constitucional cubana é excepcional no âmbito do constitucionalismo latino-americano e pode ser dividida em três grandes fases (Rojas, 2017, p. 55) ${ }^{17}$. Uma primeira fase liberal (1812-1901), correspondente ao período colonial do império espanhol que regeu a Ilha até 1898. Em seguida se verifica um constitucionalismo reformista e autonomista em sintonia com as constituições e projetos constitucionais liberais do século XIX. Cuba foi a última colônia espanhola no continente, o que demonstra um tardio intento independentista frente às posições reformistas e autonomistas da elite crioula ${ }^{18}$.

O segundo momento constitucional foi o republicano (1901-1976), que se aproximava do modelo dos Estados Unidos da América (EUA), com uma Constituição baseada nos princípios liberais da separação dos poderes e nas liberdades e direitos civis. A aproximação

\footnotetext{
${ }^{17}$ Outra demarcação da história constitucional de Cuba que merece menção é a de Carlos Manuel Villabella Armengol (2019), que a divide nas fases do Direito Constitucional Mambí, do Direito Constitucional NacionalBurguês e do Direito Constitucional Revolucionário-Socialista.

${ }^{18}$ Os crioulos eram a elite americana descendente de espanhóis, excluída dos altos cargos dirigentes, embora constituíssem a classe dos grandes proprietários de terras, dos arrendatários de minas, dos comerciantes e dos pecuaristas. Manifestavam suas insatisfações desde meados do Século XVIII e, influenciados pelo Iluminismo, iam forjando aos poucos um nacionalismo contrário ao domínio espanhol. A elite crioula impulsionou as guerras de independência em face do domínio espanhol.
} 
geográfica e política com o mercado dos EUA proporcionava a Cuba a preferência nas relações comerciais ao mesmo tempo em que ocasionava uma dependência econômica.

O terceiro é o momento socialista (a partir de 1976), pós-revolução, em que a República de Cuba foi redefinida como um Estado socialista de trabalhadores e campesinos e se autodetermina uma democracia popular com o Partido Comunista de Cuba na vanguarda da organização marxista-leninista da classe trabalhadora. De acordo com o texto constitucional de 1976, a educação, a cultura, os meios de comunicação, os direitos sociais e as formas de associação estavam sob o controle do Estado; dessa maneira, o Estado rompe radicalmente com a matriz liberal e republicana do constitucionalismo vivenciado nas Américas.

Em termos de conjuntura externa, a teoria marxista e latino-americana da dependência (Santos, 2015) é uma adequada chave analítica para se compreender o contexto e explicar a posição de Cuba na economia e geopolítica mundiais. Desde o seu início, em 1959, a Revolução cubana deflagrou um processo histórico no qual veio a ser acompanhada de um embargo econômico decretado pelos EUA, em 1960, que proíbe relações de comércio internacional entre esse país e Cuba, estendendo-se como limitação à comunidade internacional, em especial os países do bloco capitalista da Guerra Fria.

Como sabido, durante décadas a economia cubana contou com apoio político e econômico da União das Repúblicas Socialistas Soviéticas (URSS) e do Conselho de Assistência Mútua Econômica $(\mathrm{CAME})^{19}$, que foi determinante para o sustento da rede de serviços sociais (no limite, da própria soberania nacional), dadas as limitações em termos de exportações e importações em um país de economia primária baseada na extração de recursos naturais e na fabricação de açúcar e tabaco. Com a extinção da URSS, em 1991, a economia cubana foi obrigada a se reposicionar e evidenciou-se ainda mais a natureza do embargo como violência explícita dos EUA e consentida pela comunidade internacional, inclusive a ONU.

A partir desse momento, Cuba realizou reformas constitucionais decenais (1992, 2002 e 2012) voltadas a readequar seus desenhos institucionais e suas práticas sociais diante do novo cenário econômico e geopolítico mundial: (i) já não havia mais a polarização da Guerra Fria; (ii) a economia de mercado dos EUA - que ainda hoje impõe embargo econômico a Cuba - ganha protagonismo e determina ao continente americano as diretrizes do consenso de

\footnotetext{
19 Existente entre 1949 e 1991, o CAME congregava os países integrantes do mercado comum dos Estados socialistas e possibilitava ao Estado cubano adquirir produtos como, por exemplo, petróleo e máquinas, através de escambo por açúcar, cotado a preços acima do mercado mundial.
} 
Washington $^{20}$, de desregulamentação estatal da economia, para que se favoreça o livre mercado em escala mundial; (iii) espraiou-se mundo a fora o neoliberalismo (Dardot, Laval, 2016, 2017) e a sua respectiva forma jurídica, o constitucionalismo antidemocrático (Pisarello, 2011); e (iv) adveio o chamado capitalismo financeiro globalizado (Harvey, $2011)^{21}$.

Nesta nova fase do capitalismo, reconfiguraram-se as relações internacionais, digitalizou-se e dinamizou-se a economia, aumentou-se a concentração de renda. E mais:

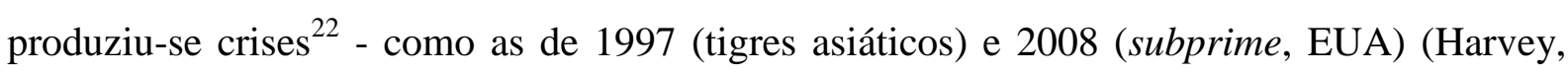
2008) - que abalaram a economia mundial e, obviamente, impactaram um país com 11 milhões de habitantes sofrendo embargo econômico há décadas, cujos parceiros internacionais são poucos e mudam com o tempo conforme as composições de governos nos diferentes países e blocos na comunidade internacional.

Por esses motivos, consideramos que existe em Cuba nas últimas décadas uma dependência externa sui generis. Não se trata da dependência de praxe - da economia de um país da periferia em relação à de países do centro do capitalismo (Santos, 2015) -, mas a dependência, por um lado, de um país da periferia da periferia em relação a países da própria

20 Consenso de Washington é o nome dado às conclusões e recomendações frutos do encontro ocorrido na capital dos Estados Unidos, no ano de 1989, cujo tema era Latin America Adjustment: How Much has Happened?. Convocados pelo Institute for International Economics, reuniram-se, naquela ocasião, economistas latino-americanos liberais, funcionários do Fundo Monetário Internacional (FMI), Banco Mundial, Banco Interamericano de Desenvolvimento (BID) e do governo norte-americano com o propósito de impulsionar reformas econômicas na América Latina. As conclusões do Consenso de Washington formam um conjunto de medidas, compostas de dez regras básicas, para promover o ajustamento macroeconômico dos países em desenvolvimento. As 10 recomendações do Consenso de Washington são: 1) disciplina fiscal - o Estado deve limitar os gastos à arrecadação, eliminando o déficit público; 2) redução dos gastos públicos; 3) reforma fiscal e tributária, na qual o governo deveria reformular seus sistemas de arrecadação de impostos e ampliar a base sobre a qual incide a carga tributária, com maior peso nos impostos indiretos; 4) abertura comercial e econômica dos países, a fim de reduzir o protecionismo e proporcionar um maior investimento estrangeiro; 5) taxa de câmbio de mercado competitivo; 6) liberalização do comércio exterior; 7) investimento estrangeiro direto, eliminando as restrições; 8) privatização, com a venda das estatais; 9) desregulamentação, com o afrouxamento das leis de controle do processo econômico e das relações trabalhistas; 10) direito à propriedade intelectual.

${ }^{21}$ Em seu recente e relevante texto, Mylai Burgos Matamoros (2019) não correlaciona as transformações no capitalismo financeiro com temas como liberdade de expressão na Ilha, articulação essa que, em nosso entender, é fundamental para a compreensão de determinadas contradições que persistem ainda nos dias de hoje. Seu marco teórico é o do chamado "autogoverno democrático, socialista, fraternal", a partir do filósofo espanhol Antoni Doménech (La democracia fraternal republicana y el socialismo de gorro frigio. La Habana: Ciencias Sociales, 2017), que nos parece muito similar à social democracia.

${ }^{22}$ A partir de estudo de Michael Bordo e outros ("Is the Crisis Problem Growing More Severe?". Economic Policy, abr., $\quad$ pp. 53-82, $2001 . \quad$ Disponível <https://siteresources.worldbank.org/DEC/Resources/cris_problem_more_severe.pdf>), Luiz Carlos BresserPereira indica que "enquanto no período de 1945 a 1971 o mundo passou por apenas 38 crises financeiras, entre 1973 e 1997 passou por 139 delas, ou seja, no segundo período houve entre três e quatro vezes mais crises do que no primeiro" (2010, p. 58). 
periferia do capitalismo (América Latina), e, por outro lado, quanto a países do cerne do capitalismo (União Europeia) ${ }^{23}$.

Portanto, para além dos assuntos domésticos, devem ser analisadas, necessariamente, considerando esse contexto mais amplo, todas as mudanças e readequações previstas nas sucessivas reformas constitucionais no texto de 1976. Tanto a manutenção de posições em defesa do projeto socialista, quanto as modificações em termos de abertura da economia e redução do monopólio do Estado na gestão e prestação de serviços como os relativos às searas da infraestrutura e do turismo, que, a partir da autorização constitucional naquelas reformas, trouxeram mais recursos e reavivaram a economia da Ilha.

Em nosso entendimento, nesse panorama devem ser analisadas as questões econômicas reconfiguradas pelas reformas constitucionais, à luz da materialidade social no processo histórico, que, como será abordado adiante, chegam ao ponto da incorporação da propriedade privada no ordenamento jurídico cubano.

O regime de propriedade previsto na Constituição de 1976 (artigo 14) era o da propriedade socialista de todo o povo sobre os meios de produção e a supressão da exploração do homem pelo homem. A Constituição contempla um amplo rol de direitos sociais nos capítulos dedicados à família, à educação e à igualdade. Os órgãos do Estado, os governos municipais e provinciais, a Assembleia Nacional, o Tribunal Supremo e o sistema eleitoral sofreram intensa centralização e o sistema político estabeleceu as eleições indiretas para chefe de Estado, com vistas a conferir mais estabilidade e segurança ao regime instaurado após Revolução cubana de 1959.

A Constituição de 1976 foi emendada em 1978 e permaneceu praticamente inalterada até 1992. No início da década de 1990, provocada pelo desaparecimento do CAME e o fim do subsídio soviético, seus principais aliados financeiros, ocorreu uma grave crise na economia que ameaçou a subsistência do povo cubano. Por tal razão, o Estado cubano precisava criar alternativas para estimular sua economia nacional e obter a renda necessária para financiar o custo das políticas públicas sociais. É essa a fase da intensa abertura para o turismo na Ilha e da exportação via contratação com países latino-americanos de mão de obra especializada, sobretudo médicos e professores, que renderia a Cuba os ingressos de renda a fim de evitar a falência dos serviços públicos existentes e do próprio Estado.

\footnotetext{
${ }^{23}$ Após mais de uma década de cooperações bilaterais, o Brasil recentemente mudou sua política externa e deixou de colaborar com Cuba. A Venezuela, na conjuntura do chavismo, e a União Europeia ainda são importantes parceiras de Cuba no plano internacional.
} 
A reforma de 1992, denominada de "Período especial em tempos de paz", representou uma atualização do modelo cubano e tinha por eixo mudanças importantes nos seguintes setores: usufruto da terra estatal por cooperativas e agricultores com o propósito de incrementar a produção agrícola e alimentar; dispensa de empregados estatais e a ampliação das atividades econômicas não estatais, estimulando-se o trabalho por conta própria (cuentapropismo) e a absorção da força de trabalho excedente; cortes em serviços sociais com vistas à diminuição do gasto público; atração de investimentos estrangeiros (empresas mistas e de capital privado) em diversos setores, sobretudo no turismo; abertura para a possibilidade de envio de recursos financeiros por imigrantes, a dupla moeda ${ }^{24}$, e o aparecimento de uma política fiscal de tributação. Em síntese, a atualização econômica visa a responder às crescentes pressões internas e internacionais que obrigaram Cuba a buscar novas formas de custear seus serviços públicos sociais e de assegurar sua autonomia econômica.

A mudança na economia cubana resultou numa complexificação social e no surgimento de novos problemas e novos atores sociais que disputam poder com o Estado. Surgem novos sujeitos econômicos: empresários capitalistas estrangeiros; trabalhadores cubanos empregados de empresas mistas; trabalhadores por conta própria (cuentapropistas); comerciantes de pequenos estabelecimentos de prestação de serviços (pequenos restaurantes e hospedagens) e seus empregados, campesinos individuais, cooperados e usufrutuários de terras, todos com expectativas diferentes e por vezes incompatíveis com a base socialista da Constituição cubana de 1976. Ampliam-se a prostituição, o mercado ilegal fomentado pela escassez e dupla moeda, e a pobreza, além do surgimento de áreas de relativa autonomia impulsionada pelo turismo e pelo ingresso de recursos estrangeiros, desafios que atualização do modelo econômico deveria enfrentar.

O período de 1996 a 2006 é compreendido como ciclo pragmático e correspondeu a uma fase de desaceleração das reformas econômicas a partir de uma intensa centralização política, numa contramarcha à abertura econômica do período anterior.

A partir de 2006, com a enfermidade de Fidel, seu irmão Raúl Castro assumiu provisoriamente o governo e promoveu mudanças nas relações com os EUA, na tentativa de

\footnotetext{
${ }^{24}$ Circulam duas moedas em Cuba: o peso nacional (CUP) e o peso conversível (CUC). A moeda utilizada pelos turistas é o CUC, que corresponde ao valor de 1 dólar americano. A taxa oficial do câmbio para a população é 25 CUP para 1 CUC. A dualidade monetária criou sérias distorções: os trabalhadores recebem seus salários em CUP, porém parte de seus gastos ocorre em CUC, que se tornou lastro de consumo por ser uma moeda de maior valor. O problema da funcionalidade de duas moedas em um mesmo país é de complexa e difícil resolução, e vem sendo enfrentado nas últimas reformas constitucionais.
} 
cancelamento do embargo econômico existente desde a década de 60. Em 2016, pela primeira vez em 88 anos, um presidente dos EUA, Barack Obama, visitou a Ilha, numa sinalização recíproca de busca por entendimentos diplomáticos e comerciais. Todavia, esse processo de aproximação se extinguiu com a chegada de Donald Trump à Casa Branca em 2017. Em 2018, Raúl Castro assumiu definitivamente o governo e propôs uma nova atualização do socialismo com um projeto para a sobrevivência do sistema político e econômico cubano. A proposta de atualização compreende mudanças administrativas e reformas estruturais que vão desde a eliminação de proibições de acesso a bens de consumo (e.g., telefones celulares), de compra e venda de casas, até a revisão da relação entre produtores privados e o Estado, a modificação de salários e pensões, a mudança na distribuição de terra, emprego, comércio e propriedade, mas mantendo-se a centralização estatal do planejamento da economia, o predomínio da empresa estatal e a aceitação de investimentos estrangeiros.

A Constituição cubana de 2019 tem por meta promover o desenvolvimento econômico apontando para o interesse geral e para a satisfação material dos cidadãos, previstos na Conceptualización del Modelo Económico y Social Cubano de Desarrollo Socialista e no Pan Nacional de Desarrollo Económico y Social hasta $2030^{25}$. Ambos os documentos foram aprovados no VII Congresso do Partido Comunista de Cuba e servem de guias para as transformações institucionais que se pretendem implementar na economia cubana. Trata-se de uma concepção de desenvolvimento econômico como desenvolvimento humano, ou seja, que não é pautado pela majoração de lucro e mercantilização de excedentes, mas pelo crescimento em termos promoção de condições dignas de vida, individual e coletivamente, com acesso materialmente igual a serviços públicos, gratuitos e de qualidade que permitam o pleno desenvolvimento dos cidadãos, sem que haja pobreza nem desigualdades socioeconômicas. ${ }^{26}$

No tocante ao direito de propriedade, a Constituição cubana de 2019 prevê no seu

\footnotetext{
${ }^{25}$ Tradução livre: Conceituação do Modelo Econômico e Social Cubano de Desenvolvimento Socialista e no do Plano Nacional de Desenvolvimento Econômico e Social até 2030.

26 Apesar das suas peculiaridades históricas, como argumentamos ao longo do texto, o modelo de desenvolvimento adotado na Constituição de Cuba remete ao Socialismo Humanista, de Ernesto Che Guevara, cujas premissas estavam calcadas no desenvolvimento de um "novo homem", emancipado dos grilhões do capitalismo e, portanto, capaz de organizar a produção da vida social e alocação de riquezas e recursos naturais em função do bem-estar real e igual para todos os homens, sem opressão de uns sobre os outros. Cf. Pericás, 2018. Nesse sentido, além de Cuba ter erradicado o analfabetismo há décadas, a Organização das Nações Unidas para a Educação, a Ciência e a Cultura - UNESCO (2015) recentemente considerou Cuba como o único país da América Latina e do Caribe a alcançar os objetivos globais para a educação, no período de 2000 a 2015 , tendo apenas um terço dos países em todo o mundo obtido o mesmo resultado. Na área de saúde, os índices também são expressivos, tendo a Organização Mundial da Saúde - WHO (2016) reconhecido elevada expectativa de vida (77/81 anos de idade) e baixa mortalidade infantil ( 5 mortes por 1000 pessoas até os 5 anos de idade).
} 
artigo 21 a possibilidade de reconhecimento da forma privada de propriedade, enumerando as formas de propriedade atualmente existentes: a socialista de todo o povo, na qual o Estado atua em representação como proprietário; a cooperativa, sustentada pelo trabalho coletivo de seus sócios proprietários; a mista, fruto da combinação duas ou mais formas de propriedade; a das organizações políticas de massa e sociais; a privada, que se exerce sobre determinados modos de produção em conformidade com o estabelecido em lei; e a pessoal, que se exerce sobre os bens que não correspondem a meios de produção, mas contribuem para a satisfação das necessidades materiais e espirituais de seus titulares.

Assim nas Constituições de Venezuela (art. 115), Equador (art. 321) e Bolívia (art. 56), a recente reforma da Constituição de Cuba legitima a propriedade privada que já existe com o controle estatal. Assim, estariam legitimados pequenos comércios, casas particulares e a exploração econômica das moradias para hospedagem de turistas, transportes de pessoas, dentre outras pequenas atividades empresariais. O Estado socialista se abre a um setor não estatal da economia e da sociedade, mas sob um controle hegemônico do Estado, previsto no artigo 22, que atribui ao Estado a regulação da propriedade de pessoas naturais ou jurídicas, com vistas a impedir a desigualdade e injustiça social, de modo que não exista a concentração de propriedade privada.

Os artigos 18 a 31, dedicados à economia, promovem uma substancial diferença em relação à Constituição de 1976, que só reconhecia a propriedade estatal e a cooperativa agropecuária, em consonância com o modelo de Estado Socialista instaurado após a Revolução de 1959. Entretanto, a reforma de 2002 já havia promovido modificações que atualmente são aperfeiçoadas.

Outra inovação da Constituição de 2019 corresponde à previsão da empresa estatal como sujeito principal da economia do país, com autonomia na administração e gestão, desempenhando um papel central na produção de bens e serviços, e fomentando a propriedade socialista de todo o povo como núcleo fundamental da sociedade. Assim, o Estado assume a função de empresário da economia cubana, que sinaliza abertura para os investimentos estrangeiros, na medida em que o projeto de reforma, em seu artigo 28, dispõe que o Estado promova e brinde garantias de investimentos estrangeiros como importantes para o desenvolvimento econômico do país. Não por acaso, empresas francesas, espanholas e, inclusive, brasileiras, a exemplo da construtora Odebrecht, promovem amplos investimentos em Cuba. 
Como será o desencadeamento desse novo modelo é algo que o futuro de Cuba reserva, eis que o Estado promete continuar exercendo um forte controle e direcionamento sobre a economia, mantendo a propriedade privada em um papel secundário e alimentando a economia cubana com investimentos estrangeiros. Sobretudo no setor turístico, com a construção de hotéis no final da década de 80 e que até hoje se mostra atrativo, aliado à construção e operação do Porto de Mariel, que corresponde a uma zona de desenvolvimento especial com participação de mais de quarenta empresas.

De certa forma, a atual Constituição parece ser um aprofundamento de reforma constitucional visando ao aperfeiçoamento do modelo socialista cubano. Essa reforma implica em transformações na estrutura na gestão da propriedade, que tendem a diminuir a presença direta do Estado na economia e o direcionamento da atuação estatal para a regulação, superando as restrições e proibições que limitavam a propriedade privada em Cuba, de modo que se constitucionaliza a legitimação da propriedade privada sob a fiscalização estatal.

O Estado cubano mantém a direção, a regulação e o controle da atividade econômica conciliando interesses nacionais, territoriais, coletivos e individuais.

A Constituição cubana de 2019 prevê que os meios de produção continuam sendo dirigidos, regulados e controlados pelo Estado, o que corresponde à característica central do socialismo, nos termos enunciados já no artigo $1^{\mathrm{o}}$ da Constituição que se apresenta como Estado Socialista de Direito de Justiça Social. Assim, reconhece que é possível existir propriedade privada no modo de produção socialista, desde que os meios de produção sejam estatais e que a economia seja fortemente regulada pelo Estado. Portanto, essa foi uma interessante maneira de permitir a pequena propriedade de moradias e sua exploração para o turismo, serviços e pequenos comércios, as chamadas cuentapropistas, pessoas que trabalham por conta própria em setores como turismo e serviços para possibilitar ou complementar renda.

Essas atividades viabilizam a subsistência das pessoas diante da escassez de recursos estatais motivada pelo embargo econômico que Cuba sofre desde a década de 60, e que foi agravada nos últimos anos com a chegada ao poder de Donald Trump nos EUA e de Jair Bolsonaro no Brasil, ressaltando-se a ruptura do contrato do Programa Mais Médicos. Assim, trata-se de alternativas para minimizar a dependência de Cuba dos parceiros internacionais.

Essa concepção de propriedade privada difere daquela de tradição europeia, na qual o Estado é um mediador na relação entre capital e trabalho. No capitalismo, o Estado assume os 
papéis de mediador e regulador da iniciativa privada, o que se diferencia consideravelmente do caminho que parece trilhar Cuba, que pretende com a Constituição de 2019 manter o monopólio estatal dos meios de produção e adotar uma forte regulação sobre os investimentos estrangeiros realizados na Ilha.

O tempo será o termômetro para que se possa verificar se Cuba será bem sucedida no propósito de manter-se fiel ao socialismo permitindo algumas formas de propriedade, especialmente a privada.

\section{Mudança no Sistema Político: o mandato do Presidente da República}

A Revolução cubana de $1^{\circ}$ de janeiro de 1959 provocou uma nova pactuação das bases do Estado na política, no direito, na sociedade e na economia. O modelo socialista do homem novo estava descrito a partir do preâmbulo constitucional de 1976, definindo a República de Cuba como Estado Socialista de trabalhadores e campesinos, e consagrando, no artigo $5^{\circ}$, o Partido Comunista de Cuba como vanguarda organizada marxista-leninista da classe trabalhadora e força dirigente da sociedade e do Estado, que orienta os esforços comuns aos altos fins da construção de uma sociedade socialista ao avanço à sociedade comunista.

Assim, Cuba rompe com a matriz liberal do constitucionalismo americano ao institucionalizar o sistema de partido político único, que possui função institucional, nos termos do artigo $5^{\circ}$ da Constituição de 1976. O Partido Comunista Cubano é um partido político institucional e dirigente da sociedade, o que não se confunde com partido político eleitoral. O processo de representação política em Cuba difere da democracia partidária representativa liberal, pois não é obrigatória a filiação partidária para ser candidato em um pleito eleitoral e qualquer cidadão/ã cubano/a pode se candidatar a ocupar uma das vagas de delegados/as da Assembleia Municipal do Poder Popular.

Talvez essa seja uma das maiores dificuldades de compreensão sobre o funcionamento do sistema político da Ilha, já que difere substancialmente do sistema brasileiro, que exige como requisito imprescindível de elegibilidade a filiação do/a cidadão/ã a partido político. Em Cuba, o direito de escolher e apresentar os/as candidatos/as a Delegados/as às Assembleias Municipais do Poder Popular é exclusivamente dos/as eleitores/as e são eleitores/as todos/as os/as cidadãos/as cubanos/as a partir dos 16 anos de idade, que estejam em pleno gozo dos 
seus direitos políticos, o que está previsto nos artigos 134 a 137 da Constituição cubana de 1976.

Trata-se do poder popular sem o intermédio de partidos políticos. O exercício desse direito se dá nas assembleias gerais das áreas de circunscrição eleitoral nas quais os/as eleitores/as estejam vinculados/as. A circunscrição eleitoral é uma divisão territorial do Município e constitui a célula fundamental do Sistema do Poder Popular.

O Sistema do Poder Popular se apresenta em Cuba da seguinte maneira: no nível nacional, a Assembleia Nacional do Poder Popular; em cada uma das províncias, as Assembleias Provinciais do Poder Popular; nos municípios, as Assembleias Municipais; no nível de comunidade, os Conselhos Populares - cada Conselho agrupa várias circunscrições eleitorais e é integrado pelos/as seus/suas delegados/as, dirigentes de organizações de massas e representantes de entidades administrativas. Os/As Deputados/as na Assembleia Nacional e os/as Delegados/as nas demais Assembleias não recebem remuneração específica pelo exercício do mandato popular e continuam exercendo suas profissões em seus locais de trabalho, recebendo o salário correspondente.

A Assembleia Nacional se reúne duas vezes ao ano, as Provinciais Municipais com maior frequência. Os/As Deputados/as e Delegados/as exercem seus mandatos junto aos seus eleitores, prestando-lhes contas periodicamente e podendo, de acordo com a Lei, ser destituídos da função de representação a qualquer momento, caso não estejam correspondendo aos compromissos assumidos perante o povo.

O Partido Comunista Cubano é composto pelos trabalhadores e pelas trabalhadoras, mediante um processo deliberativo em Assembleia, constitui-se em um órgão de representação político-institucional e presta contas das decisões em seus congressos. $\mathrm{O}$ Partido sugere e propõe pautas à Assembleia Nacional do Poder Popular e ao Governo. É uma instituição dialógica entre a sociedade civil, a Assembleia Nacional e o Governo. Todavia, ao ser definido constitucionalmente como força dirigente superior da Sociedade e do Estado, ao Partido Comunista Cubano é conferido o status de instituição protagonista do Estado. Essa é a previsão do artigo $5^{\circ}$ da Constituição de 1976: 
El Partido Comunista de Cuba, martiano y marxista-leninista, vanguardia organizada de la nación cubana, es la fuerza dirigente superior de la Sociedad y el Estado, que organiza y orienta los esfuerzos comunes hacia los altos fines de la construcción del socialismo y el avance hacia la sociedad comunista. $\left(\right.$ Cuba, 1976). ${ }^{27}$

Da mesma maneira, a reforma constitucional referendada em 2019 repete as competências e a função de protagonismo do Partido Comunista Cubano também no seu art. $5^{\circ}$ :

\begin{abstract}
El Partido Comunista de Cuba, único, martiano, fidelista y marxista-leninista, vanguardia organizada de la nación cubana, sustentado en su carácter democrático y la permanente vinculación con el pueblo, es la fuerza dirigente superior de la sociedad y del Estado. Organiza y orienta los esfuerzos comunes hacia la construcción del socialismo. Trabaja por preservar y fortalecer la unidad patriótica de los cubanos y por desarrollar valores éticos, morales y cívicos. (Cuba, 2019). ${ }^{28}$
\end{abstract}

A semelhança entre os dispositivos e atribuições, tanto do Partido Comunista Cubano quanto da Assembleia Nacional do Poder Popular, revela que não houve mudança significativa de atribuições ou ruptura com a ordem jurídica anterior, tendo sido mantida a centralidade do PCC.

São os/as deputados/as da Assembleia Nacional, dentre os seus pares, que elegem o Presidente Cubano. A Constituição de 1976 não trazia previsão de duração do mandato presidencial. O ex-presidente Fidel Castro governou Cuba do início da Revolução Cubana até 2006, quando por força da sua enfermidade passou interinamente o cargo para Raúl Castro, seu irmão caçula. Em fevereiro de 2008, em razão do afastamento definitivo de Fidel, Raúl foi eleito pela Assembleia Nacional para presidir Cuba e iniciou um período de mudanças significativas.

Raúl Castro implementou algumas medidas de abertura política e econômica, e adotou uma política internacional de diálogo e negociações com os EUA para o restabelecimento das relações diplomáticas, como afirmamos acima. Cuba participou da $7^{\mathrm{a}}$ Cúpula das Américas em 2015 e esta foi a primeira reunião de líderes dos 35 países do Continente Americano com

\footnotetext{
${ }^{27}$ Tradução livre: "O Partido Comunista de Cuba, martiano e marxista-leninista, vanguarda organizada da nação cubana, é a força dirigente superior da Sociedade e do Estado, que organiza e orienta os esforços comuns para os altos fins da construção do socialismo e o avanço para a sociedade comunista. (artigo $5^{\circ}$ da Constituição da República de Cuba Proclamada em 24 de fevereiro de 1976)".

${ }^{28}$ Tradução livre: "O Partido Comunista de Cuba, único, martiano, fidelista e marxista-leninista, vanguarda organizada da nação cubana, sustentado em seu caráter democrático e na permanente vinculação com o povo, é a força dirigente superior da sociedade e do Estado. Organiza e orienta os esforços comuns para a construção do socialismo. Trabalha para preservar e fortalecer a unidade patriótica dos cubanos e para desenvolver valores éticos, morais e cívicos. (artigo 5º da Constituição da República de Cuba Proclamada em 10 de abril de 2019)”.
} 
a participação do governo cubano, que até então tinha sido vetada pelos EUA. A notícia representou a possibilidade de reaproximação entre os EUA e Cuba, que romperam relações diplomáticas desde a década de 60. Com a eleição de Donald Trump, as tratativas de aproximação ficaram prejudicadas.

A morte de Fidel Castro em 2016 gerou um forte questionamento a respeito do futuro político do país, que vem sinalizando para a ideia de substituição do personalismo do governo pela institucionalidade da escolha temporária e democrática dos próximos presidentes da República, de modo que haja uma renovação dos ocupantes temporários do poder político.

Em 19 de abril de 2018 foi eleito para presidir Cuba Miguel Mario Díaz-Canel Bermúdez, que ocupava o cargo de vice-presidente. $\mathrm{O}$ atual presidente foi eleito pela Assembleia Nacional do Poder Popular e obteve 99,84\% dos votos dos/as 604 deputados/as, ou seja, a unanimidade, já que apenas ele próprio não votou. Miguel Díaz-Canel iniciou o mandato de 5 anos que poderá ser renovado por igual período. Essa é uma das principais inovações da atual reforma constitucional, prevista nos artigos 121 e seguintes. O texto atual também possibilita uma renovação etária ou geracional, já que a reforma prevê no artigo 122 que para ser postulante ao cargo de presidente o/a candidato/a deve ter entre 35 e 60 anos de idade na primeira candidatura, ou seja, os próximos presidentes no exercício do cargo terão, no máximo, 70 anos de idade. Díaz-Canel representa uma renovação no governo, que, desde a Revolução cubana, era ocupado pela família Castro. Ele também é o primeiro presidente que não participou da Revolução Cubana, pois nasceu em 1960, um ano após o triunfo revolucionário.

Embora a atual reforma preveja o exercício temporário do cargo de Presidente da República, a eleição indireta foi mantida. Os próximos presidentes continuarão sendo eleitos pela maioria dos/as deputados/as da Assembleia Nacional do Poder Popular, cujos/as 604 deputados/as são eleitos/as pelos/as cidadãos/as cubanos/as, nos termos do artigo 104 da atual reforma constitucional.

Será de Díaz-Canel a tarefa de liderar a busca e a implementação das reformas necessárias com vistas a atualizar o socialismo com base na Constituição de 2019, cujo processo de elaboração acompanhou de perto, desde a redação até a proclamação.

\section{Considerações Finais}


A Constituição da República de Cuba de 2019 gera um compromisso entre as gerações que vivenciaram o início e o desenvolvimento da Revolução cubana, e as atuais destinatárias das conquistas revolucionárias, que são e serão as presentes e futuras responsáveis pelo exercício do poder político e a continuidade das transformações sociais e econômicas.

Isso implica na mudança, nas transformações e, ao mesmo tempo, na lealdade aos valores e princípios fundacionais que pautam a construção de uma sociedade justa e solidária, com todos e todas para o bem de todos e todas.

Esse é o desafio na construção de uma democracia agonística que tem como pressuposto a construção de identidades políticas comprometidas com a democracia pluralista e a disputa entre elas. Transformar relações antagônicas em agônicas possibilita uma ampliação da democracia que nos parece ser um dos propósitos da Constituição cubana de 2019. Isso significou a consolidação de um texto comprometido com a criação de regras do jogo que pressupõem a pluralidade de ideias, gerações, concepções de Estado e de valores numa disputa agonística.

O poder popular em Cuba requer um redimensionamento de sua estruturação, organização e funcionalidade. Esta exigência demanda o fortalecimento dos(as) representantes populares e uma maior participação da sociedade nas decisões políticas.

A legitimidade democrática da reforma da constitucional se apresenta como um elemento de sobrevivência do sistema político cubano. Deve orientar-se na busca de um equilíbrio entre condições materiais e mecanismos políticos que permitam que o modelo socialista cubano se apoie em estandartes democráticos.

A ratificação do texto pela cidadania por meio de referendo e uma abertura dialógica entre a sociedade civil que sugeriu modificações do projeto inicial de constituição até se chegar à versão final do texto sinaliza uma aproximação entre a Constituição cubana de 2019 e o novo constitucionalismo latino-americano. Importa também destacar que o texto final incluiu a cidadania como titular do poder constituinte derivado, o que pode representar também um avanço do ponto de vista democrático.

Também representa o desafio reconhecer o trabalho, a propriedade privada e buscar soluções econômicas que passam pela abertura ao capital, sem perder o horizonte dos objetivos da Revolução e do papel do Estado enquanto agente promotor de direitos sociais e cidadania, mas reconhecendo o custo econômico desses direitos. 


\section{Bibliografia}

ABENSOUR, Miguel. A democracia contra o Estado: Marx e o momento Maquiaveliano. Belo Horizonte-MG: Ed. UFMG, 1998.

ARBLASTER, Anthony. A democracia. Lisboa: Editorial Estampa, 1988.

ÁVILA SANTAMARÍA, Ramiro. El neoconstitucionalismo andino. Quito: Universidad Andina Simón Bolivar / Huaponi Ediciones, 2016.

BARBOSA, Maria Lúcia. Democracia direta e participativa: um diálogo entre a democracia no Brasil e o novo constitucionalismo latino-americano. 2015. $218 \mathrm{f}$. Tese (doutorado) Curso de Direito, Universidade Federal de Pernambuco, Recife, 2015.

BELLO, Enzo. "Constituição e Política na Venezuela: Um balanço da conjuntura contemporânea”. Pensar - Revista de Ciências Jurídicas, Fortaleza, v. 24, n. 1, pp. 1-13, 2019. Disponível em: <http://https://periodicos.unifor.br/rpen/article/view/7661>. Acesso em 13 ago. 2019.

BELLO, Enzo. A cidadania no constitucionalismo latino-americano. 2 ed. Rio de Janeiro-RJ: Lumen Juris, 2018.

BOBBIO, Norberto. O futuro da democracia: uma defesa das regras do jogo. $6^{\text {a }}$ ed. Rio de Janeiro-RJ: Paz e Terra, 1997.

BONAVIDES. Paulo. Curso de Direito Constitucional. 33 ed., São Paulo-SP: Malheiros, 2018.

BONAVIDES, Paulo. Ciência Política. 10ª ed. São Paulo-SP: Malheiros, 2000.

BRESSER-PEREIRA, Luiz Carlos. "A crise financeira global e depois: um novo capitalismo?”. Novos Estudos CEBRAP, São Paulo, n. 86, mar., pp. 51-72, 2010. Disponível em: 〈http://www.scielo.br/pdf/nec/n86/n86a03.pdf >. Acesso em 20 ago. 2019.

BURGOS MATAMOROS, Mylai. “A nova constituição da República de Cuba: autogoverno republicano, democrático, socialista e fraternal". Revista Culturas Jurídicas, Niterói, Vol. 06, n. 13, pp. 1-38, 2019. Disponível em: <http://culturasjuridicas.uff.br/index.php/rcj/article/view/803/368>. Acesso em 13 ago. 2019.

BURGOS MATAMOROS, Mylai. "Análisis Crítico Constitucional de los Cambios Sociojurídicos en la Cuba Actual”. Revista Direito e Práxis, Rio de Janeiro, Vol. 08, n. 4, pp. 3169-3216, 2017. Disponível em: <https://www.epublicacoes.uerj.br/index.php/revistaceaju/article/view/31315>. Acesso em 16 ago. 2019.

CUBA. Constitución de la República de Cuba. La Habana, 2019. Disponível em: <http://www.granma.cu/file/pdf/gaceta/Nueva\%20Constituci\%C3\%B3n\%20240\%20KB1.pdf>. Acesso em 13 jul. 2019. 
CUBA. Introducción al análisis del Proyecto de Constitución de la República durante la consulta popular. La Habana, 2019.

CUBA. Parlamento Cubano. Proyecto de Constitución de la República de Cuba. La Habana, 2018.

CUBA. Constitución de la República de Cuba. La Habana, 1976. Disponível em: $<$ http://www.cervantesvirtual.com/obra-visor/constitucion-de-la-republica-de-cuba-de-1976incluye-la-reforma-constitucional-del-26-de-mayo-2002/html/> . Acesso em 23 ago. 2019.

DARDOT, Pierre; LAVAL, Christian. A nova razão do mundo: ensaio sobre a sociedade neoliberal. São Paulo-SP: Boitempo, 2016.

DARDOT, Pierre; LAVAL, Christian. La pesadilla que no se acaba nunca: el neoliberalismo contra la democracia. Barcelona: Gedisa, 2017.

DOIMEADIOS GUERRERO, Dianet; CARMONA TAMAYO, Edilberto; PÉREZ, Irene. "Cuba ratifica la nueva Constitución con el $86.85 \%$ de los votos emitidos, según datos preliminares". Cuba Debate - contra el terrorismo midiático. 25/02/2019. Disponível em: $<$ http://www.cubadebate.cu/noticias/2019/02/25/cuba-constitucion-referendoresultados/\#.XVQ7-2NqNR1>. Acesso em 30 mai. 2019.

EDELMAN, Bernard. A legalização da classe operária. São Paulo-SP: Boitempo, 2016.

GARGARELlA, Roberto. La sala de máquinas de la Constitución. Dos siglos de constitucionalismo en América Latina (1810-2010). Buenos Aires: Katz, 2010.

GRAMSCI, Antonio. Cadernos do Cárcere. Vol. 3. Maquiavel. Notas sobre o Estado e a política. Rio de Janeiro-RJ: Civilização Brasileira, 2007.

HARVEY, David. O enigma do capital e as crises do capitalismo. São Paulo-SP: Boitempo, 2011.

HARVEY, David. "The right to the city". New Left Review, n. 53, sept./oct., pp. 23-40, 2008. Disponível em: <https://newleftreview.org/issues/II53/articles/david-harvey-the-right-to-thecity>. Acesso em 11 ago. 2019.

HORKHEIMER, Max. "Teoria Tradicional e Teoria Crítica”. In: Os Pensadores. Rio de Janeiro-RJ: Ed. Abril Cultural, 1983, pp. 125-162.

LACLAU, Ernesto; MOUFFE, Chantal. Hegemonia e Estratégia Socialista: por uma política democrática radical. São Paulo-SP: Intermeios; Brasília-DF: CNPQ, 2015.

LACLAU, Ernesto. A Razão Populista. São Paulo-SP: Três Estrelas, 2013.

LENIN, Vladimir Ilych Ulyanov. O Estado e a Revolução: doutrina do marxismo sobre o Estado e as tarefas do proletariado na Revolução. São Paulo-SP: Boitempo, 2017.

LYRA FILHO, Roberto. O que é direito. 20ª ed. São Paulo: Brasiliense, 2000. 
MARES, Carlos. "Cuba e sua nova Constituição”. Revista-PUB. 30/06/2019. Disponível em:< https://www.revista-pub.org/post/01072019>. Acesso em 27 jul. 2019.

MARX, Karl. O 18 Brumário e cartas a Kugelmann. 7a Ed., Rio de Janeiro-RJ: Paz e Terra, 2002.

MARX, Karl. Crítica da filosofia do direito de Hegel. São Paulo-SP: Boitempo, 2005.

MORAIS, Fernando. A Ilha. São Paulo-SP: Cia das Letras, 2001.

MOUFFE, Chantal. O Regresso do Político. Lisboa: Grandiva, 1996.

MOUFFE, Chantal. Sobre o Político. São Paulo-SP: Editora WMF Martins Fontes, 2015.

PERICÁS, Luiz Bernardo. Che Guevara e o debate econômico em Cuba. São Paulo-SP: Boitempo, 2018.

PISARELLO, Gerardo. Procesos constituyentes: Caminos para la ruptura democrática. Madrid: Trotta, 2014.

PISARELLO, Gerardo. Un largo termidor: La ofensiva del constitucionalismo antidemocrático. Madrid: Trotta, 2011.

QUIJANO, Aníbal. "Colonialidade do poder, eurocentrismo e América Latina". In: LANDER, Edgardo (comp.). A colonialidade do saber: eurocentrismo e ciências sociais: perspectivas latino-americanas. Buenos Aires: CLACSO, 2000, pp. 107-130.

ROJAS, Rafael; BOBES, Velia Cecilia; CHAGUACEDA, Armando (coords.). El cambio constitucional en Cuba. Actores, instituciones y leyes de un proceso político. México D.F.: FCE, 2017.

SALAMANCA SERRANO, Antonio. Teoria Socialista del Derecho: iusmaterialismo. Tomo I. Quito: Editorial Jurídica del Ecuador, 2011a.

SALAMANCA SERRANO, Antonio. Teoria Socialista del Derecho. Tomo II. Quito: Editorial Jurídica del Ecuador, 2011 b.

SANÍN RESTREPPO, Ricardo. Teoría crítica constitucional: rescatando la democracia del liberalismo. Quito: Corte Constitucional para el Período de Transición, 2011. Disponível em: $<$ https://www.corteconstitucional.gob.

ec/images/stories/corte/pdfs/teoria_critica_constitucional_1.pdf >.

SANTOS, Theotônio dos. Teoria da Dependência: balanço e perspectivas. Florianópolis-SC: Ed. Insular, 2015.

UNESCO. United Nations Educational, Scientific and Cultural Organization. Education for All 2000-2015: Only Cuba reached global education goals in Latin America and the Caribbean. 09/04/2105. Disponível em: <https://en.unesco.org/gem-report/sites/gemreport/files/Latin_AmericaPR_en.pdf >. Acesso em 11. set. 2019. 
VALENÇA, Daniel. De costas para o Império: o Estado Plurinacional da Bolívia e a luta pelo socialismo comunitário. Rio de Janeiro-RJ: Lumen Juris, 2018.

VILLABELLA ARMENGOL, Carlos Manuel. "El derecho constitucional cubano de 1812 al 2009: cánones, ciclos y modelos políticos”. Revista de História Constitucional, n. 20, pp. 887-918 2019. Disponível em: <http://www.historiaconstitucional.com/index.php/historiaconstitucional/article/view/575/pdf _96>. Acesso em 20 set. 2019.

WHO. World Health Organization. Country Health Profile - Cuba. 2017. Disponível em: $<$ https://www.who.int/countries/cub/en/>. Acesso em 02 set. 2019.

WOOD, Ellen Meiksins. Democracia contra capitalismo: a renovação do materialismo histórico. São Paulo-SP: Boitempo, 2003.

\title{
A Constituição da República de Cuba de 2019: ampliação democrática e regulação econômica como desafios do tempo presente ao socialismo real
}

\section{Resumo}

Este artigo apresenta e discute o Projeto de Constituição aprovado pela Assembleia do Poder Popular de Cuba, em 21 e 22 de julho de 2018, para substituição da Constituição de 1976 e validado por referendo popular em 24 de fevereiro de 2019. Essa proposta é compreendida como tentativa de democratização do exercício do poder constituinte para uma aproximação com o constitucionalismo democrático latino-americano. São apresentadas algumas inovações quanto ao texto de 1976, especialmente as mudanças na economia, o reconhecimento da propriedade privada, além da implementação de mecanismos de escolha e mandato do Presidente da República. A metodologia envolve pesquisa qualitativa, raciocínio dedutivo e indutivo, e referencial teórico-metodológico da teoria crítica da sociedade capitalista e do Direito. A pesquisa tem perfil multidisciplinar e teórico-normativo, articulando os campos do Direito Constitucional, da Economia e da Política. As técnicas de pesquisa utilizadas são as de revisão bibliográfica e análise documental. As fontes de pesquisa são documentos legislativos, artigos e livros acadêmicos, além de dados extraídos de órgãos oficiais, jornais e periódicos. As principais conclusões ressaltam que o novo texto constitucional tenta adaptar o socialismo real às demandas políticas de maior participação e econômicas de acesso a novas fontes de renda.

Palavras chave: Cuba; Constituição de 2019; Democracia; Economia e Política.

\section{The Constitution of The Republic of Cuba of 2019: democratic amplification and economic regulation as challenges from present time to the real socialismo}

\begin{abstract}
This paper presents and discusses the Project of Constitution approved by the Assembly of Popular Power of Cuba, in July 21 and 22, 2018, to the substitution of the Constitution of 1976 and validated through popular referendum in February 24, 2019. This proposition is understood as an attempt democratize the exercise of the constituent power to an approach with the Latin American New Constitutionalism. Some innovations referring to the text of 1976 are presented, especially the changes in the economy, the recognition of private property, besides além the implementation of de mecanismos de nomination and mandate of the President of the Republic. The methodology involves qualitative research, deductive and inductive reasoning, and theoreticalmethodological guidelines from the Critical Theory of the capitalist society and Law. The research has multidisciplinary and theoretical-normative profile, connecting the fields of Constitutional Law, Economics and Politics. The techniques of research adopted are bibliographical review and documentary analysis. The sources of research legislative documents, academic papers and books, besides data extracted from official institutions,
\end{abstract}


newspapers and journals. The main conclusions underline the new constitutional text tries to adapt real socialism to the political and economic demands of widen participation and access to new incomes.

Keywords: Cuba; Constitution of 2019; Democracy; Economics and Politics.

\section{La Constitución de la República de Cuba de 2019: ampliación democrática y regulación económica como retos desde el tiempo presente a el socialismo real}

\section{Resumen}

Este texto presenta y discute el Proyecto de Constitución aprobado por la Asamblea del Poder Popular de Cuba, en 21 y 22 de julio de 2018, para substitución de la Constitución de 1976 y validado por referéndum popular el 24 de febrero de 2019. Esa propuesta es compreendida como intento de democratización del ejercicio del poder constituyente para una aproximación con el constitucionalismo democrático latinoamericano. Son presentadas algunas innovaciones quanto a el texto de 1976, especialmente los cambios en la economía, el reconocimiento de la propiedad privada, más allá de la implementación de mecanismos de elección y mandato del Presidente de la República. La metodología envolve investigación cualitativa, raciocinio deductivo e inductivo, y referencial teórico-metodológico de la teoría crítica de la sociedad capitalista. La investigación tiene perfil multidisciplinar y teórico-normativo, articulando los campos del Derecho Constitucional, de la Economía y de la Política. Las técnicas de investigación adoptadas son las de revisión bibliográfica e análisis documental. Las fuentes de investigación son documentos legislativos, artículos y libros académicos, más allá de datos extraídos de órganos oficiales, periódicos y revistas académicas. Las principales conclusiones subrayan que el nuevo texto constitucional intenta adaptar el socialismo real a las demandas políticas de mayor participación y económicas de acceso a nuevas fuentes de renta.

Palabras clave: Cuba; Constitución de 2019; Democracia; Economía y Política. 